\title{
BINGKAI MEDIA DI MASA PRA PANDEMI COVID-19 DI INDONESIA (Studi Framing Pemberitaan Covid-19 di Portal Berita dan Akun Youtube Tribunnews Edisi Maret 2020)
}

\section{MEDIA FRAME ON PRE-PANDEMIC COVID-19 IN INDONESIA (Framing Study on Covid-19 News in News Portals and Youtube Account Tribunnews March 2020 Edition)}

\author{
Rohmah Nia Chandra Sari ${ }^{1}$, Rachmat Kriyantono ${ }^{2}$, Desi Dwi Prianti ${ }^{3}$ \\ ${ }^{1,2,3}$ Program Studi Ilmu Komunikasi, Universitas Brawijaya \\ Jl. Veteran, Lowokwaru, Kota Malang, Indonesia \\ ${ }^{1}$ rohmahniacandra@student.ub.ac.id, ${ }^{2}$ rachmat_kr@ub.ac.id, ${ }^{3}$ desidwip@ub.ac.id
}

Diterima tgl. 17/03/2021; Direvisi tgl. 08/12/2021; Disetujui tgl. 15/12/2021

\begin{abstract}
Covid-19 has become a new health problem that never happened before. Information about health issues is important, especially in the pre-pandemic to anticipate the outbreak. Media as the main source of information has an important role in delivering messages. This research aims to analyze the frame used by media youtube and news portals tribunnews in the pre covid-19 coverage in Indonesia during March 2020. The method in this research used framing analyze by Robert Entman, by four functions of frames there are problem definition, causal interpretation, moral evaluation and treatment recommendation. We choose news by purposive sampling technique. The result of the research showed that in the covid-19 coverage information is dynamic. Although the news is presented through two different platforms, namely news portal and youtube, it does not show a significant difference in information content. Researchers divided this coverage by three periods, first period on 1-10 March 2020 shows a frame of calm and builds enthusiasm in facing the pandemic, the second period 11-20 March frame the covid-19 was changed to a threat and risk, the third period 21-31 shows covid19 frame as cautious and fear because it shows aspects of victims, economic downturns and variety other threats.
\end{abstract}

Keywords : Covid-19, Framing Media, Tribunnews

\begin{abstract}
ABSTRAK
Covid-19 menjadi masalah kesehatan baru yang belum pernah terjadi sebelumya. Informasi mengenai isu kesehatan tersebut menjadi penting terutama di pra-pandemi untuk mengantisipasi menyebarnya wabah. Media sebagai sumber informasi utama memiliki peranan yang penting dalam penyampaian pesan. Penelitian ini bertujuan menganalisis bingkai media youtube dan portal berita tribunnews dalam pemberitaan awal covid-19 di Indonesia selama bulan Maret 2020. Metode yang digunakan dalam penelitian ini adalah analisis framing dari Robert Entman, melalui empat fungsi bingkai yaitu mendefinisikan sebuah masalah, memperkirakan sumber masalah, membuat keputusan moral, dan menekankan penyelesaian masalah. Pemilihan pemberitaan melalui teknik purposive sampling Hasil dari penelitian ini menunjukkan bahwa dalam pemberitaan covid-19 di Indonesia menunjukkan informasi yang dinamis. Meskipun pemberitaan disajikan melalui dua platform yang berbeda yaitu portal berita dan youtube, tidak menunjukkan perbedaan isi informasi yang signifikan. Peneliti membagi pemberitaan menjadi tiga periode, periode pertama pada tanggal 1-10 Maret 2020 yang menunjukkan bingkai ketenangan dan membangun semangat dalam menghadapi pandemi, periode kedua 11-20 Maret bingkai covid-19 dirubah menjadi suatu ancaman dan resiko yang perlu diwaspadai, periode ketiga yakni 2131 bingkai covid-19 menampilkan kewaspadaan dan ketakutan karena menunjukkan aspek korban, penurunan ekonomi dan berbagai ancaman lainnya.
\end{abstract}

Kata Kunci : Covid-19, Framing Media, Tribunnews

\section{PENDAHULUAN}

Covid-19 atau Corona merupakan penyakit baru yang menjadi perhatian bagi berbagai lapisan masyarakat di seluruh dunia. (Welle, 2020) yang menyatakan bahwa terhitung sejak awal Januari, virus covid-19 mulai menyebar ke negara lain selain China, Thailand sebagai negara pertama yang 
melaporkan kasus pertamanya, puncak penyebaran virus ini adalah bulan Maret 2020, sebanyak 244.000 orang terinfeksi, 160 negara terdampak dan 10.000 manusia meninggal dunia, Indonesia menjadi satu dari 160 negara yang terdampak oleh wabah ini. Covid-19 memberikan pengaruh yang sangat besar dalam masalah kesehatan yang menyebabkan kewaspadaan bagi seluruh warga didunia, kondisi ini disampaikan langsung oleh Direktur Badan Kesehatan Dunia (Assegaf, 2020).

Terdampaknya negara Indonesia oleh wabah covid-19 ini padah tanggal 2 Maret 2020 dimana presiden mengumumkan adanya warga negara yang terinfeksi covid-19 (Wahyono, 2020). Kasus pertama di Indonesia berbeda rentang waktunya dengan negara lain seperti Thailand, Taiwan, Amerika Serikat dan Jerman yang melaporkan kasus pertamanya (Welle, 2020). Indonesia dinilai sebagai negara yang terlambat dalam penanganan virus corona. Beberapa tokoh penting di Indonesia menyatakan kekecewaannya pada pemerintah karena kurang seriusnya dalam penanganan wabah ini, hal ini diungkapkan oleh Usman Hamid sebagai Direktur Eksekutif Amnesty International Indonesia yang menyayangkan sikap pemerintah pada saat periode awal penyebaran covid-19 (Briantika, 2020). WHO menjelaskan bahwa pentingnya penanganan pada pra pandemi akan meminimalisir peningkatan kasus dan korban meninggal, sehingga wabah akan lebih mudah dikendalikan (Briantika, 2020)

Jika dilihat dalam proses penyebaran, Indonesia termasuk salah satu negara yang cukup lama terinfeksi dari negara lain. Informasi mengenai munculnya wabah covid-19 di China adalah bulan Desember, sedangkan negara Indonesia sendiri memberikan pengumuman warganya yang terinfeksi pada bulan Maret 2020. Tentunya terdapat waktu kurang lebih empat bulan untuk mempersiapkan dan mengantisipasi virus ini sebelum masuk di negara Indonesia. Pemerintah, tim medis, dan masyarakat bersatu melakukan upaya pencegahan dan penyembuhan wabah covid sesuai dengan kapabilitasnya masing-masing, termasuk media yang ikut berupaya memberikan informasi. Proses peminimalisiran angka penyebaran virus covid-19 dipengaruhi oleh beberapa faktor, salah satu faktor yang memiliki peranan yang penting dalam meminimalisir covid-19 adalah media (González-padilla, 2020). Peran komunikasi melalui pemberitaan media menjadi penting karena bencana merupakan situasi yang memerlukan koordinasi informasi dan tindakan dari berbagai pihak untuk ditangani dengan benar (Kriyantono, 2019b, h. 2)

Media dipergunakan pemerintah sebagai alat untuk menyampaikan informasi atau pemberitaan mengenai covid 19, berdasarkan data yang diperoleh, 63\% keberhasilan yang dilakukan oleh pemerintah untuk meminimalisir tingkat penyebaran covid-19 yang menyerang seluruh dunia ini adalah melalui informasi yang diberikan oleh media (González-padilla, 2020). Berry (dalam Wibhisono, 2020) menjelaskan bahwa media memiliki posisi yang penting dalam proses penyampaian informasi kepada publik, media dapat meningkatkan kesadaran masyarakat mengenai masalah kesehatan, bahkan mendukung kebijakan yang berkaitan dengan kesehatan. Sesuai dengan fungsi media yakni media sebagai pengawasan yang memberikan informasi mengenai kejadian disekitar dan fungsi korelasi yang mencakup interpretasi dari media massa yang mengambil, memaknai serta memberikan kritik terhadap fenomena sosial yang ada di lingkungannya (Nugroho, 2016, h. 24). Saat ini media terus mengalami perkembangan, seiring dengan perkembangannya, tentu informasi yang disampaikan akan memberikan pengaruh terhadap isi pemberitaan yang akan disampaikan kepada publik, kondisi inilah yang biasa disebut sebagai pembingkaian suatu berita atau framing (Rachmawati et al., 2019, h. 20). Proses jurnalisme yang terjadi pada media membangun bagaimana sebuah informasi mengenai kesehatan disajikan kepada publik (Stryker, 2010, h. 2096). Informasi mengenai perilaku kesehatan menghasilkan suatu efek yang bertahap, misalnya bingkai yang digunakan suatu media dapat menghasilkan efek persuasif yang berbeda dari setiap penerima pesan (Stryker, 2010). 
Penelitian terdahulu yang dilakukan oleh (Ogbodo et al., 2020) menjelaskan bahwa media memiliki peranan yang penting dalam menangani covid-19, sebagai alat penyampai informasi kepada masyarakat, informasi tersebut dinilai penting untuk menerangi atau mengatasi krisis kesehatan covid-19 yang mungkin akan memberikan dampak jangka panjang bagi kesehatan masyarakat. Dalam situasi krisis, pemberitaan sangat diperlukan, apalagi saat ini media memiliki peranan yang penting dalam penanganan wabah (Vos \& Buckner, 2016). Krisis terjadi dan berkembang karena adanya faktor kekurangan dan kelebihan informasi, dan kegagalan untuk menyediakan dan mengontrol aliran informasi yang ada (Kriyantono, 2019b, h. 94). Untuk menghadapi krisis diperlukan semangat dan terus berjuang untuk bertahan, serta perlunya pengelolaan yang baik dalam penanganan krisis (Kriyantono, 2019, h. 33). (Rudianto et al., 2015) Pada saat terjadi bencana, komunikasi hadir karena adanya kebutuhan publik dalam mengurangi kondisi ketidakpastian. Situasi yang berisiko, menyebabkan ketidakpastian dan spekulasi yang luar biasa (Wibhisono, 2020). Pada saat terjadi bencana, salah satu langkah yang bisa dilakukan untuk menangani bencana adalah dengan menyajikan informasi-informasi yang nyata dan berisikan fakta. (Putra, 2020) berita mengenai covid19 yang beredar memberikan dampak yang besar, berbagai pemberitaan mengenai peningkatan kasus, adanya isolasi, atau karantina, berbagai peraturan pemerintah hingga korban jiwa dapat memicu berbagai masalah kesehatan. Beberapa ahli menyatakan bahwa informasi tersebut bisa memberikan dampak ketakutan, kecemasan, emosi yang tidak terkontrol, gangguan tidur hingga depresi.

Selain sebagai sumber informasi, masyarakat juga menempatkan pemberitaan sebagai suatu pedoman dalam menyusun suatu agenda sesuai dengan fungsi dari jurnalisme bencana bahwasanya pemberitaan digunakan untuk membantu masyarakat maupun pihak yang terkait untuk menanggulangi suatu bencana (Panuju, 2018). (Viswanath, 2010) menjelaskan bahwa media memberikan peranan penting dalam membentuk sudut pandang khalayak mengenai risiko-risiko kesehatan, media juga memiliki kemampuan dalam mengkonstruksi informasi mengenai risiko kesehatan melalui teks atau isi pesan yang ditampilkan. (Berry, 2007) menjelaskan bahwa meskipun media memiliki peranan yang sangat vital, namun media juga memiliki dampak positif dan negatif. Salah satu dampak positif dari media adalah dapat meningkatkan kesadaran masyarakat tentang masalah kesehatan. Dampak negatifnya adalah media juga akan mengalami masalah jika menyajikan pemberitaan yang tidak akurat, dan tidak lengkap (Berry, 2007). Pemberitaan yang tidak lengkap dan tidak akurat biasanya terjadi karena sifat dari jurnalis sendiri yang didasarkan pada ketepatan dan kecepatan waktu serta kecenderungan media untuk mengabaikan faktor kontekstual dalam berita kesehatan (Stryker, 2010).

(Eriyanto, 2002) Menjelaskan bahwa framing atau pembingkaian merupakan pemilihan sebuah realitas yang membuat realitas tersebut lebih terlohat dalam sebuah teks komunikasi melalui penekanan definisi dari sebuah permasalahan, bagaimana masalah itu terjadi, bagaimana nilai moral yang ada, serta bagaimana penyelesaian dalam sebuah permasalahan. (Kriyantono, 2019b) menjelaskan bahwasanya analisis framing digunakan untuk mengetahui sudut pandang yang digunakan oleh jurnalis dalam proses penyeleksian isu dan penulisan berita. Bagaimana sebuah realitas tersebut dibingkai, dikonstruksi serta dimaknai oleh media. (Syahri, 2009) berita memiliki ruang sebagai pembentuk serta pengolah dari suatu fenomena maupun peristiwa manusia, dimana berita memiliki peranan yang sangat penting dalam proses konstruksi sosial. Pada kondisi tertentu, media dapat mempengaruhi seseorang untuk memberikan cara pandang mengenai fenomena disekitarnya. Media tidak hanya alat untuk menyalurkan pesan saja, melainkan di dalam sebuah pemberitaan terdapat subjek yang mengkonstruksi sebuah realitas yang lengkap dengan paradigma, bias maupun keberpihakannya (Negara \& Rusadi, 2020). Pandangan tersebut merupakan frame yang dibuat untuk memberikan gambaran mengenai bagaimana sebuah fenomena itu dipahami. Jika 
bingkai yang disajikan mengenai kejadian, pengalaman maupun peristiwa itu tidak jelas, maka semua hal tersebut akan terlihat berantakan (Syahri, 2009). (Quarantelli, 1991) menjelaskan gambaran bagaimana masyarakat dalam melihat sebuah bencana tidak jarang dipengaruhi melalui bagaimana media memberikan gambaran atas mereka. Maka dari itu, bingkai yang dikonstruksi oleh media memberikan peranan yang penting dalam penentuan sikap dan respon publik terhadap apa yang harus dilakukan.

Beberapa studi terdahulu seperti yang dilakukan oleh (Ogbodo et al., 2020) mengenai pembingkaian pemberitaan online yang terjadi di Nigeria membuktikan bahwa bingkai yang dibentuk oleh media adalah bingkai ketakutan yang membuat masyarakat cenderung mengalami tingkat kewaspadaan dan frustasi yang berlebihan. Kasus covid-19 berkembang secara cepat di Nigeria karena pembingkaian pemberitaan media dan sampai Desember 2020, 78.434 orang sudah terinfeksi kasus covid-19. Hasil sebaliknya didapatkan dari penelitian yang dilakukan (Mutua \& Oloo, 2020) tentang bingkai media online di China yang menemukan bahwa media di China membingkai Covid-19 sebagai sebuah wabah yang bisa disembuhkan, informasi yang disampaikan juga memberikan edukasi bagi warga dalam penanganan virus corona seperti tahapan penyebaran, identifikasi gejala hingga cara penanganannya. Dapat disimpulkan dari kedua temuan di atas bahwa media membingkai bencana covid-19. Media di Nigeria membingkai ketakutan bagi masyarakatnya dan menimbulkan dampak frustasi pada masyarakatnya sedangkan media China membingkai berita dengan isi yang lebih edukatif dan informatif. Ada kaitan dengan keberhasilan China yang lebih mampu mengatasi virus covid-19 di negaranya beberapa saat lalu. Riset terdahulu menjadi acuan peneliti untuk melakukan pengembangan terkait penelitian mengenai framing pemberitaan pandemi khusunya di negara Indonesia.

Media sebagai sebuah platform penyaji jasa informasi maupun hiburan kepada publik tidak dapat dianggap netral. Pasalnya, media memiliki realitas yang tersusun dari hasil pandangan tertentu, yang pada akhirnya menghasilkan realitas media (Sobur, 2009). Indikasi media berperan dalam membentuk realitas dapat dilihat dari beberapa hal, seperti pembingkaian peristiwa yang dilaporkannya dan dalam memberikan tanda tertentu pada sebuah fenomena dan siapa yang menjadi pemeran dalam sebuah pemberitaan. Analisis framing jika ditinjau dalam perspektif komunikasi dimanfaatkan untuk mengkaji sebuah praktik maupun ideologi dari media saat mengkonstruksi sebuah realitas. (Sobur, 2009).

Teori konstruksi realitas sosial digunakan untuk memahami bagaimana pengetahuan yang dimiliki manusia dikonstruksi melalui interaksi sosial (John \& Foss, 2011). Penggambaran sederhananya, para anggota sebuah komunitas saling berkomunikasi satu sama lain menggunakan bahasa dan menghasilkan realitas sosial sebagai sebuah proses konstruksi bersama. Sebagai unsur konstruksi realitas, bahasa adalah sebuah konsep dan alat penyampai pesan (Chong \& Druckman, 2016).

Menurut (Eriyanto, 2002) ditinjau dari sudut pandang konstruktivis, media, wartawan, dan berita memiliki keterikatan, fakta dan realitas adalah hasil konstruksi yang mengandung sudut pandang dari wartawan, wartawan merupakan agen konstruksi realitas karena pilihan moral, keberpihakan, dan etikanya memengaruhi dalam penyusunan berita. Media merupakan agen konstruksi, media merupakan subjek yang mengonstruksi realitas yang tercampur dengan bias, pandangan, serta pemihakannya. Berita bukan refleksi dari realitas, dimana hasil tersebut merupakan hasil dari konstruksi realitas yeng melibatkan berbagai aspek seperti ideologi, nilai wartawan maupun dari media itu sendiri. Berita yang hadir pada sebuah media merupakan salah satu bentuk keberagaman dalam penyampaian realitas kepada publik. Berita pada dasarnya memiliki sifat yang subjektif, hal ini dikarenakan opini maupun sudut pandang dari wartawan tidak bisa dihilangkan (Karman, 2012, h. 3). 
Realitas tidak dapat begitu saja hadir dalam bentuknya yang mentah, namun realitas harus disaring melalui bagaimana cara seseorang memandang setiap kondisi yang ada (Karman, 2013). Hal ini sejalan dengan pemikiran Berger dan Luckmann (dalam (Wibhisono, 2020) bahwasanya realitas tidak dapat hadir begitu saja, namun dibentuk dan dihasilkan melalui kesadaran tertentu yang menghadirkan keberadaan suatu objek melalui intens tertentu dalam konstruksinya (Sitompul, 2014).

Media mengkonstruksi informasi dan memberikannya kepada publik. Media dimaknai tidak netral, namun media dapat terpengaruh dari sudut pandang internal organisasi media maupun dari pihak luar media. Hal ini berlaku pula bagi masyarakat yang tidak hanya sekedar menerima informasi dari media namun ia mengkonstruksinya berdasarkan pandangan masing-masing. Proses dalam pembentukan realitas dapat dilakukan melalui dua cara antara lain melalui bahasa ataupun penandaan politik. (Karman, 2012) menjelaskan bahwasanya penandaan politik merupakan praktik social yang dilakukan untuk membentuk makna, mengontrol serta menentukan makna tersebut. Media sendiri memiliki peranan untuk memberikan tanda suatu fenomena melalui makna tertentu. William A. Gamson menjelaskan bahwasanya proses dalam konstruksi sosial terjadi melalui dua tahapan yang saling berkaitan dalam konstruksi sosial untuk memaknai sebuah realitas.

(Karman, 2012, h. 4) Tahapan yang pertama adalah individual atau interpretatif. Individu dalam melakukan sesuatu mengaitkan tentang pengalaman yang dialami, pengetahuan sosial dan aspek psikologis dalam memaknai sesuatu. Pengalaman serta pengetahuan yang dimiliki individu inilah yang dapat menyeleksi, menerima, mengidentifikasi serta memberi tanda pada suatu peristiwa yang dialami. Sedangkan tahapan yang kedua yaitu wacana atau kultural, bingkai dapat memberika petunjuk mengenai elemen isu yang sesuai untuk diwacanakan, permasalahan apa yang memerlukan aksi serta solusi yang sesuai untuk diambil dan pihak mana yang sesuai dengan wacana yang dibentuk.

Frame atau bingkai dapat menjadi petunjuk bagi seseorang dalam mempersepsikan hal disekelilingnya yang beragam. Frame didapatkan melalui kumpulan berbagai informasi yang dirasakan seseorang sebagai suatu fakta (Butsi, 2019). Pada kondisi selanjutnya, Erving Goffman mengembangkan pemikiran awal Bateson pada ruang yang lebih luas dan berkembang. Erving Goffman menjelaskan bahwasanya bingkai sebenarnya merupakan sesuatu yang dapat dipelajari dan dimanfaatkan dalam siklus kehidupan dan keseharian masyarakat serta menjadi dasar dalam melakukan segala sesuatu. Dengan mempelajari mengenai pembingkaian yang hadir ditengah masyarakat, akan memberikan panduan bagi seseorang untuk bersosialisasi serta berbaur dengan masyarakat tersebut. Tanpa frame, peristiwa yang kita lihat sehari-hari akan tampak acak dan tidak beraturan. Agar peristiwa bermakna dan memiliki arti, seseorang melihat dengan frame tertentu, sehingga bisa memahami dunia sekitar dan lingkungan (Eriyanto, 2002).

Berdasarkan latar belakang yang telah diuraikan, memunculkan pertanyaan mengenai bagaimana Tribunnews dalam mengkonstruksi realitas covid-19 di masa pra pandemi, serta bagaimana bingkai yang ada dalam pemberitaannya. Penelitian ini memiliki tujuan untuk mengetahui bagaimana media Tribunnews dalam mendeskripsikan covid-19 di awal kemunculannya di Indonesia melalui bingkainya. Alasa pemilihan Tribunnews sebagai media penyampai informasi dikarenakan: pertama, Tribunnews aktif dan intens dalam memberikan pemberitaan mengenai covid-19. Mayoritas pemberitaan yang disajikan oleh Tribunnews di bulan Maret 2020 adalah covid-19. Kedua, berdasarkan data dari badan riset Alexa, Tribunnews dinilai sebagai media di Indonesia yang paling sering dicari oleh publik selama pandemi.

Dari penjabaran di atas, peneliti dapat melihat bahwa individu menghasilkan dunia sosial melalui kata-kata, tindakan, dan melalui produk media. Untuk itu mempelajari teks media adalah salah satu upaya dalam memahami realitas sosial, termasuk terkait framing atau pembingkaian peristiwa oleh media. 


\section{METODE PENELITIAN}

Penelitian ini menggunakan pendekatan kualitatif. (Mulyadi, 2012) menjelaskan bahwa pendekatan kualitatif menekankan pada suatu makna serta pemahaman dari dalam diri, bagaimana penalarannya, mendefinisikan dari situasi tertentu, lebih banyak meneliti mengenai hal-hal yang berhubungan dengan keseharian. Paradigma penelitian ini konstruktivis yang digunakan peneliti untuk melihat realita, mempelajari fenomena dan cara untuk menginterpretasikan sebuah temuan. Metode analisis yang digunakan adalah framing dari Robert Entman. (Reese, 2007) menjelaskan bahwa melalui analisis framing, peneliti akan menganalisis isi dari suatu pemberitaan, menemukan tema yang nanti dapat ditemukan hubungan antara teks yang satu dan lainnya. Dengan menggunakan analisis framing, penelitian ini nantinya akan memaparkan bagaimana bingkai dari pemberitaan covid-19 yang dilakukan oleh Tribunnews pada bulan Maret 2020 melalui empat elemen framing Robert Entman.

Objek dalam penelitian ini adalah akun youtube tribunnews dan portal berita tribunnews.com. Pemilihan media tribunnews ini dikarenakan beberapa hal, berdasarkan data dari Alexa (2020), tribunnews menjadi media yang paling sering diakses, selain itu tribunnews merupakan media nasional sehingga cakupan pemberitaannya luas. Pemberitaan yang akan dianalisis melalui analisis framing Robert Entman adalah pemberitaan yang diunggah oleh portal berita dan akun youtube mengenai covid-19 dari tanggal 1 Maret 2020 hingga 31 Maret 2020. Pemilihan bulan Maret dikarenakan merupakan fase awal covid-19 masuk ke Indonesia, sehingga dengan melakukan penelitian ini diharapkan bisa memberikan langkah selanjutnya untuk menangani pandemi. Data primer pemberitaan dikumpulkan dengan menelusurinya langsung pada portal berita tribunnews.com dan akun youtube tribunnews. Total pemberitaan yang akan peneliti analisis berjumlah 104 pemberitaan dengan tiga hingga empat pemberitaan per harinya. Untuk portal berita tribunnews.com peneliti akan menganalisis teks pemberitaannya dengan total 63 pemberitaan, sedangkan untuk youtube peneliti akan mentranskrip audio dari video sehingga berbentuk teks dengan total 31 video. Teknik pemilihan jenis pemberitaan melalui teknik purposive sampling. Kriteria pemberitaan yang digunakan dalam pemilihan sampel adalah judul pemberitaan menggunakan kata kunci "covid-19" atau corona, dan diunggah pada rentang waktu 1-31 Maret 2020.

Pada proses analisis data, peneliti membaca judul hingga isi berita secara keseluruhan, kemudian mengklasifikasikan pemberitaan empat unsur framing menurut Robert Entman. Teknis analisis data yang digunakan dalam penelitian ini menggunakan analisis framing dari Robert Entman. Robert Entman, melihat sebuah bingkai dalam dua dimensi besar, antara lain seleksi isu dan penonjolan aspek tertentu dari sebuah isu (Eriyanto, 2002). Isu yang terpilih berkaitan terhadap bagaimana pemilihan suatu realitas, ketika realitas tersebut telah dipilih maka akan mempengaruhi bagaimana realitas tersebut ditulis (Kriyantono, 2020). Hal tersebut sangat terkait dengan kata yang dimaknai, kalimat-kalimat, gambar maupun gambaran untuk ditampilkan pada publik. Robert Entman telah merumuskan model framing melalui empat tahapan. Pertama, bagaimana masalah tersebut didefinisikan, dilihat sebagai apa dan sebagai permasalahan apa. Kedua, masalah tersebut hadir disebabkan oleh apa, yang menjadi suatu penyebab itu apa, dan siapa tokoh yang dianggap menjadi masalah. Ketiga, bagaimana nilai moral yang ada untuk menjelaskan sebuah permasalahan, yang digunakan untuk melegitimasi maupun mendelegitimasi tindakan. Keempat atau yang terakhir adalah bagaimana masalah tersebut dapat diselesaikan melalui tawaran-tawaran yang diberikan oleh media (Rachmawati et al., 2019) 


\section{HASIL DAN PEMBAHASAN}

\subsection{Pemberitaan Covid-19 Pada Portal Berita Tribunnews.com dan Akun Youtube Tribunnews}

Setelah menjelaskan metode penelitian, peneliti akan mencoba menyajikan hasil analisis pemberitaan dari portal berita online dan transkrip teks dari unggahan video di akun youtube tribunnews.com periode bulan Maret 2020. Peneliti akan menyajikan sekitar 3 hingga 4 pemberitaan per-harinya untuk membatasi banyaknya pemberitaan yang di unggah di akun youtube maupun portal berita tribunnews. Berdasarkan data yang peneliti peroleh melalui observasi, terdapat sekitar 100200 pemberitaan di portal berita tribunnews.com per-harinya mengenai covid-19. Sedangkan pada akun youtube hanya sekitar 20-100 unggahan video per harinya mengenai covid-19. Hal ini memperlihatkan bahwa media memberikan perhatian yang besar terkait wabah dengan menerbitkan banyak pemberitaan mengenai pandemi covid-19 di Indonesia. Peneliti menemukan bahwasanya pemberitaan dalam jumlah besar tidak semuanya beragam, terdapat beberapa pemberitaan yang memiliki isi pemberitaan serupa namun dikemas dengan judul yang berbeda.

Metode analisis framing dari Robert Entman digunakan untuk menganalisis bagaimana tribunnews dalam membingkai kasus covid-19 pada Bulan Maret. Metode analisis framing Robert Entman dipilih oleh peneliti karena penelitian ini berfokus pada analisis teks pada berita. Maka dari itu peneliti akan melihat pembingkaian yang dibangun oleh tribunnews dari empat fungsi bingkai, yakni bagaimana masalah itu didefinisikan, bagaimana masalah itu hadir, nilai moral, serta bagaimana media dalam menyelesaikan masalah (Kriyantono, 2020).

Sejak kasus pertama yang diumumkan oleh Presiden Indonesia pada tanggal 2 Maret, pemberitaan mengenai kasus covid-19 hampir setiap hari menjadi berita yang sering diunggah oleh media, terlihat dari unggahan pemberitaan yang mencapai puluhan hingga ratusan perharinya. Media menyajikan berbagai informasi mulai data dari perkembangan pasien positif covid-19, penanggulangan dan kebijakan yang dilakukan pemerintah hingga pelaku industri dalam menghadapi pandemi, serta perlunya kerjasama seluruh lapisan masyarakat untuk menghentikan terjadinya pandemi. Berita yang muncul secara bebas akan dikonsumsi publik yang menimbulkan berbagai pemaknaan dan reaksi.

Hasil data yang diperoleh menunjukkan dinamisasi informasi setiap 10 hari unggahan pemberitaan. Pemberitaan pada rentang waktu 1-10 Maret 2020 mayoritas memberikan informasi mengenai pemberitaan hoaks yang berkembang serta adanya kasus pertama di Indonesia. Rentang waktu 11-20 Maret menunjukkan informasi mengenai pelayanan pemerintah terkait korban pandemi, serta terus bertambahnya kasus positif di Indonesia. Sedangkan rentang waktu 21-31 Maret 2020 pemberitaan berisikan mengenai korban jiwa dan penurunan berbagai sektor, salah satunya ekonomi karena adanya pandemi. Maka dari itu, untuk memudahkan dalam menganalisis bingkai pemberitaan tribunnews, peneliti akan membingkai kasus dengan mengklasifikasikan pemberitaan menjadi tiga periode untuk melihat kesenjangan informasi yang terjadi. Periode pertama pada tanggal 1-10 Maret 2020, periode kedua pada 11-20 Maret 2020, periode ketiga pada 21-31 Maret 2020. Dari data yang diperoleh peneliti melalui portal berita online dan akun youtube tribunnews.com akan peneliti analisis melalui metode analisis framing Robert Entman.

\subsection{Periode Pertama: Ketenangan dan Harapan di Tengah Pandemi}

Periode pertama yang peneliti klasifikasikan pada tanggal 1-10 Maret 2020 berjumlah 32 pemberitaan dengan bingkai ketenangan dan harapan yang mendominasi. Berdasarkan hasil analisis data yang peneliti temukan, terdapat 20 pemberitaan yang menenangkan, selain itu terdapat pemberitaan yang menakutkan dan kewaspadaan. Pada periode ini media lebih banyak memberitakan bagaimana peranan pemerintah dalam meminimalisir pemberitaan hoaks, karena pada masa awal 
pandemi banyak sekali pemberitaaan bohong yang tersebar luas di masyarakat. Selain itu media juga menampilkan informasi mengenai keseriusan pemerintah dalam penanganan wabah, seperti adanya batasan-batasan warga negara asing yang ingin berkunjung di Indonesia. Pasien pertama di Indonesia yang terinfeksi penyakit covid-19 juga turut diberitakan oleh media, pemerintah menindaklanjuti serius terhadap pasien positif covid-19 dengan memberikan pelayanan sebaik mungkin untuk kesembuhan pasien. (Hinnant et al., 2017) menjelaskan bahwa dalam mencari informasi maupun menampilkan pemberitaan publik mengenai kesehatan, jurnalis harus memposisikan pemerintah dan beberapa ahli sebagai sumber informasi yang utama. Hal ini sesuai dengan temuan dalam penelitian ini seperti pada pemberitaan pada tanggal 1 Maret 2020. Berikut salah satu pemberitaan pada tanggal 1 Maret 2020.

Tabel 1. Contoh Judul Berita Tanggal 1-10 Maret 2020

\begin{tabular}{|c|c|c|c|}
\hline No & Judul Berita & Tanggal Berita & Media \\
\hline 1 & $\begin{array}{l}\text { Awas Hoaks Virus Corona, Menkominfo Bakal } \\
\text { Proses Hukum Penyebar Hoaks: Indonesia Steril }\end{array}$ & 1 Maret 2020 & Portal Berita \\
\hline 2 & $\begin{array}{l}\text { BNPB Minta Warga Waspadai Berita Hoaks } \\
\text { Seputar Virus Corona }\end{array}$ & 1 Maret 2020 & Youtube \\
\hline 3 & $\begin{array}{l}\text { Semua Media Besar Jepang Ikut Beritakan Kasus } \\
\text { Virus Corona Pertama di Indonesia }\end{array}$ & 3 Maret 2020 & Portal Berita \\
\hline 4 & $\begin{array}{l}\text { Bareskrim Tersangkakan } 5 \text { Penyebar Hoaks Virus } \\
\text { Corona }\end{array}$ & 5 Maret 2020 & Portal Berita \\
\hline 5 & $\begin{array}{l}\text { Kondisi Terkini } 4 \text { Pasien Positif Corona di } \\
\text { Indonesia, Pasien } 03 \text { dan } 04 \text { Menunjukkan } \\
\text { Perubahan }\end{array}$ & 7 Maret 2020 & Portal Berita \\
\hline 6 & $\begin{array}{l}\text { WNI Positif Corona Jadi Enam Orang, Salah } \\
\text { Satunya ABK Diamond Princess }\end{array}$ & 9 Maret 2020 & Portal Berita \\
\hline 7 & $\begin{array}{l}\text { Pemerintah Umumkan } 19 \text { Pasien di Indonesia } \\
\text { Positif Virus Corona, Ada yang Masih Berusia } \\
\text { Belasan Tahun }\end{array}$ & 9 Maret 2020 & Youtube \\
\hline 8 & $\begin{array}{l}\text { Selasa Pagi, Kominfo Deteksi } 187 \text { Hoaks Terkait } \\
\text { Virus Corona }\end{array}$ & 10 Maret 2020 & Youtube \\
\hline
\end{tabular}

Sumber : Hasil olah data

Pada rentang waktu 1-10 Maret 2020, pemberitaan yang diunggah oleh portal berita dan akun youtube tribunnews mayoritas berisikan mengenai pemberitaan hoaks yang terus berkembang. Definisi dari permasalahan tersebut adalah adanya kondisi, dimana wabah dijadikan sebagai suatu bahan informasi yang tidak benar untuk menarik perhatian masyarakat luas. Pendefinisian masalah ini diperkuat oleh pernyataan dari Kementrian Komunikasi dan Informatika, Jhonny G. Plates yang diunggah pada portal berita tribunnews (Wutsqa, 2020) bahwa :

"Diketahui, penyebaran berita bohong atau berita hoax per tanggal 25 Februari 2020 terdapat total 127 hoaks terkait dengan virus Corona. Sedangkan hingga hari Minggu (1/3/2020) terdapat penambahan hoaks menjadi 142 isu.",

Selain pemberitaan hoaks yang menyebar, kondisi pasien positif corona terus bertambah, pasien tersebut dari berbagai kalangan dan jenis usia antara lain anak-anak hingga lansia. Diagnose causes atau permasalahan ini terjadi karena masih kurangnya pengetahuan masyarakat dalam menerima informasi terkait corona, sehingga segala informasi diterima mentah-mentah oleh masyarakat, pelaku penyebar hoaks juga meraup untung dari penyebaran berita. Selain itu, terdapat beberapa warga yang memiliki gejala mirip corona setelah berinteraksi dengan warga yang positif corona. Make moral judgement atau nilai moral daari permasalahan ini adalah hoaks dan penambahan kasus yang berkembang membuat khawatir berbagai pihak, salah satunya BNPB, hal ini diperkuat oleh ungkapan dari (Tribunnews, 2020) bahwa: 
"berita hoaks lebih berbahaya daripada penyebaran wabah virus yang sebenarnya."

Treatment recommendation atau penyelesaian dari permasalahan ini adalah dilakukan penangkapan bagi penyebar hoaks, serta memidanakan pelaku. Tindakan tersebut memiliki tujuan agar pelaku penyebar hoax jera dan tidak mengulanginya lagi. Selain itu Kementrian Komunikasi dan Informasi menurunkan pemberitaan-pemberitaan yang tidak jelas kebenarannya. Pemerintah juga terus melakukan upaya tracing atau pengecekan demi meminimalisir terjadinya kenaikan kasus.

Dengan demikian, melihat dari analisis pemberitaan melalui empat elemen bingkai Robert Entman, tribunnews mengkonstruksi pandemi ini sebagai sebuah langkah untuk menenangkan masyarakat melalui bingkai pemerintah yang tanggap dengan penyebaran hoaks sebagai suatu langkah untuk meminimalisir terjadinya informasi atau berita hoaks yang berkembang. Disisi lain, bingkai yang dibentuk juga menimbulkan kewaspadaan, hal ini dikarenakan banyaknya pemberitaan bohong, sehingga masyarakat hati-hati dalam menerima informasi. Bingkai yang dibentuk tribunnews pada akun youtube juga hampir sama dengan portal berita.

\subsection{Periode Kedua: Kewaspadaan Terhadap Pandemi}

Periode kedua yang peneliti klasifikasikan pada tanggal 11-20 Maret 2020 berjumlah 36 pemberitaan dengan bingkai ketenangan dan kewaspadaan yang mendominasi. Informasi yang ditampilkan media mulai berkembang dan terjadi perubahan. Perubahan yang paling terlihat adalah dalam periode awal, informasi-informasi yang menenangkan, namun pada periode ini bingkai yang ditampilkan media mengenai covid-19 sebagai sebuah kewaspadaan. Bingkai berita kewaspadaan mencapai 19 berita dari 36 pemberitaan yang peneliti pilih, dengan 17 berita yang menenangkan.

Tabel 2. Contoh Judul Berita Tanggal 11-20 Maret 2020

\begin{tabular}{|c|c|c|c|}
\hline No & Judul Berita & Tanggal Berita & Media \\
\hline 1 & $\begin{array}{l}27 \text { Pasien Positif Corona di Indonesia, } 1 \mathrm{di} \\
\text { Antaranya Masih Misterius, Belum Tahu Asal } \\
\text { Terjangkitnya }\end{array}$ & 11 Maret & Portal Berita \\
\hline 2 & $\begin{array}{l}\text { RSPI Sulianto Saroso soal Dua Pasien Positif } \\
\text { Virus Corona Meninggal: Di Sini Hanya Satu }\end{array}$ & 13 Maret 2020 & Portal Berita \\
\hline 3 & $\begin{array}{l}\text { Data } 35 \text { Pasien Baru Positif Virus Corona, } \\
\text { Kini Total Ada } 69 \text { Orang }\end{array}$ & 14 Maret 2020 & Portal Berita \\
\hline 4 & $\begin{array}{l}7 \text { Kasus Baru Pasien Positif Covid-19 di } \\
\text { Jabar, Ridwan Kamil: Ada Satu Pasien } \\
\text { Meninggal }\end{array}$ & 16 Maret 2020 & Youtube \\
\hline 5 & $\begin{array}{l}\text { Update Kasus Virus Corona di Indonesia, } \\
\text { Pasien Positif Jadi } 172 \text { Kasus }\end{array}$ & 17 Maret 2020 & Youtube \\
\hline 6 & $\begin{array}{l}\text { Jumlah Penderita Virus Corona Cenderung } \\
\text { Naik, Ini Penjelasan Pemerintah }\end{array}$ & 18 Maret 2020 & Portal Berita \\
\hline
\end{tabular}

Sumber : Hasil olah data

Pemberitaan yang disajikan banyak mengambil sudut pandang pemerintah, dengan menyajikan informasi pencegahan, dan kasus peningkatan yang cukup signifikan. Berita mempresentasikan bagaimana pemerintah Indonesia telah berusaha menekan angka penyebaran dengan mengeluarkan berbagai kebijakan seperti physical distancing, social distancing dan protokol kesehatan. Pada rentang waktu 11-20 Maret 2020, definisi permasalahan yang terjadi adalah asal pasien itu terjangkit, korban meninggal dunia serta penambahan kasus yang cukup signifikan. Diagnose causes atau permasalahan ini terjadi karena adanya penambahan kasus dari 35 kasus positif mencapai 172 kasus, beberapa rumah sakit di Indonesia juga menyatakan bahwa adanya korban jiwa dari wabah covid19. Beberapa pasien terkonfirmasi positif juga belum diketahui asal penularannya. Nilai moral dari periode ini adalah adanya kerjasama yang dilakukan oleh pemerintah dengan rumah sakit di seluruh 
lapisan daerah di Indonesia untuk dapat memaksimalkan dan peningkatan ruang bagi masyarakat positif covid-19, upaya untuk mencegah melalui pengecekan asal penularan juga terus dilakukan oleh pemerintah. Treatment recommendation dari permasalahan ini adalah pemerintah membentuk satuan gugus tugas penanganan covid-19 yang nantinya akan bekerja sama dengan

berbagai stakeholder seperti ASN, TNI, Polri untuk ikut mencegah terjadinya wabah. Sosialisasi pemerintah daerah juga dilakukan agar masyarakat bisa mematuhi protokol kesehatan yang berlaku.

Dengan demikian, redaksi mengkonstruksi untuk waspada terutama di daerah Jakarta dan sekitarnya karena kasus covid-19 paling banyak, selain itu redaksi menyajikan informasi bahwa pemerintah melakukan berbagai cara untuk menangani pandemi seperti melibatkan seluruh stakeholder dalam penanganan covid, informasi ini dapat mengurangi kepanikan yang terjadi di masyarakat serta meningkatkan kewaspadaan, karena covid-19 telah menyebabkan korban meninggal dunia.

\subsection{Periode Ketiga: Kewaspadaan dan Ketakutan Terhadap Pandemi}

Periode ketiga yang peneliti klasifikasikan pada tanggal 21-31 Maret 2020 berjumlah 36 pemberitaan dengan bingkai kewaspadaan dan ketakutan yang mendominasi. Berdasarkan hasil analisis data yang peneliti temukan, terdapat 15 pemberitaan yang berisikan informasi untuk tetap waspada terhadap pandemi, 10 ketakutan dan beberapa mengenai ketenangan. Pada periode ini media lebih banyak memberikan informasi-informasi mengenai kenaikan kasus pasien positif corona, penularan virus yang mudah, dampak corona yang mengakibatkan terjadinya penurunan ekonomi, hingga kondisi dilapangan yang masih kurang dalam alat perlindungan diri.

Tabel 3. Contoh Judul Berita Tanggal 21-31 Maret 2020

\begin{tabular}{llll}
\hline No & Judul Berita & Tanggal Berita & Media \\
\hline 1 & $\begin{array}{l}\text { Gawat, Sudah 17 Provinsi di Indonesia } \\
\text { Terjangkit Corona, 13 Daerah di Aceh } \\
\text { Berstatus Waspada }\end{array}$ & 21 Maret 2020 & Portal Berita \\
2 & $\begin{array}{l}\text { Dampak Corona, Mall Plaza Indonesia Akan } \\
\text { Tutup Sepekan Lebih }\end{array}$ & 23 Maret 2020 & Portal Berita \\
3 & $\begin{array}{l}\text { RS Persahabatan Update Pasien Covid19, } \\
\text { Pasien di Ruang IGD Berjumlah 24 Orang }\end{array}$ & 24 Maret 2020 & Youtube \\
4 & $\begin{array}{l}\text { Pemberdayaan Sektor Informal yang } \\
\text { Terdampak Wabah Virus Corona }\end{array}$ & 26 Maret 2020 & Portal Berita \\
5 & $\begin{array}{l}\text { Dampak Wabah Corona, Kadin DKI Sebut } \\
\text { Perekonomian Jakarta Turun 60 Persen }\end{array}$ & 27 Maret 2020 & Portal Berita \\
6 & $\begin{array}{l}\text { Ekonomi Indonesia Tahun Ini Diprediksi } \\
\text { Hanya Tumbuh 2,1 Persen karena Virus } \\
\text { Corona }\end{array}$ & 31 Maret 2020 & Portal Berita \\
\hline \multicolumn{1}{c}{ Sumber : Hasil olah data }
\end{tabular}

Pada rentang waktu 21-31 Maret 2021 mendefinisikan sebuah permasalahan bahwa covid-19 sudah menyebar di berbagai provinsi seluruh Indonesia, korban jiwa terus meningkat dan berbagai sektor mengalami kerugian, antara lain gagalnya pemberangkatan kereta api, tutupnya berbagai tempat perbelanjaan, dan sektor ekspor impor. Diagnose causes atau permasalahan ii terjadi dikarenakan adanya perlonjakan kasus covid-19 di Indonesia, sehingga berdampak pada berbagai sektor. Make moral judgementa tau nilai moralnya adalah masyarakat harus lebih meningkatkan kewaspadaan, covid-19 telah memberikan kerugian bagi masyarakat maupun negara. Treatment recommendation atau penyelesaian masalah adalah pengembalian tiket kepada masyarakat yang tidak jadi pergi keluar kota karena adanya pembatalan perjalanan, adanya pemberdayaan berbagai 
sektor untuk menghadapi penurunan ekonomi karena wabah, serta terus dilakukan upaya pencegahan melalui penutupan akses keluar masuk daerah.

Dengan demikian, konstruksi yang terbentuk adalah covid-19 menyebabkan berbagai kerugian baik sektor ekonomi maupun dari masyarakat sendiri. Bingkai yang terbentuk adalah adanya ketakutan dan kewaspadaan karena korban jiwa yang terus meningkat serta menyebarnya virus ini di berbagai wilayah. Sektor ekonomi menurun, serta berkurangnya mobilitas perjalanan karena adanya larangan keluar masuk wilayah.

Secara umum, pada bulan maret 2020 frame media juga berkorelasi dengan peran kehumasan pemerintah. Humas pemerintah menjadi sumber utama media dalam mencari sumber berita. Karena itu, Humas pemerintah harus memberikan asupan informasi secara aktif, berkala dan dengan frame yang positif (Kriyantono, 2019c).

\subsection{Pembahasan}

Menjadi sebuah fenomena baru, pandemic covid-19 menjadi perhatian bagi berbagai pihak, terutama media massa dalam memberikan informasi mengenai kasus kesehatan, hal ini menjadi penting karena menyangkut kondisi dan kehidupan masyarakat (Fahrimal et al., 2020). Berdasarkan data yang diperoleh peneliti, dari 104 pemberitaan akan dibagi menjadi 3 periode untuk mempermudah untuk mengklasifikasikan pembingkaian. Hasil dari pembingkaian tersebut ditemukan bahwa ada 35 pemberitaan yang membingkai ketenangan, 26 bingkai kewaspadaan, ketakutan 9, kepanikan 1, dan 2 harapan dari pemberitaan di portal berita online, sedangkan pada pemberitaan yang diunggah oleh akun youtube tribunnews menunjukkan 10 berita bingkai ketenangan, 11 bingkai waspada dan 9 ketakutan. Kewaspadaan, ketakutan, ketenangan dan-lain-lain merupakan realitas dari kontruksi yang dibentuk oleh media. Masyarakatlah yang memberikan makna terhadap sesuatu. Ditinjau dari periodenya, kebanyakan pemberitaan berisikan informasi yang sudut pandangnya mengarah pada pemerintah.

Media portal berita online tribunnews.com cenderung lebih banyak mengunggah berita-berita mengenai covid-19, sekitar 100-200 pemberitaan diunggah per-harinya. Sedangkan pada media youtube tribunnews hanya mengunggah 20-100 video per harinya. Pemberitaan di youtube yang ditampilkan berisikan gambar dengan teks berjalan, video yang disertai voice over, dan ada juga video yang disertai presenter.

Menurut (Eriyanto, 2002), tentang konstruksi realitas sosial bahwa media memiliki keterikatan dalam membangun fakta dan realitas yang merupakan hasil dari sudut pandang wartawan. Pemberitaan yang disajikan oleh tribunnews merupakan sebuah fakta, hal ini dikarenakan dalam pemberitaan tribunnews memunculkan berbagai macam sumber untuk menjadi dasar penulisan berita. Tribunnews banyak mengambil opini atau pendapat dari pemerintah, antara lain dari Gugus Tugas Percepatan Penanganan Covid-19 di Indonesia yang merupakan perwakilan dari pemerintahan, beberapa sumber ahli seperti kepala kementrian maupun pihak BUMN. Selain itu tribunnews juga mengambil pendapat dari berbagai ahli, seperti dokter yang menangani pasien corona, peneliti maupun tokoh masyarakat. Dengan demikian, kredibilitas dari pemberitaan dapat terjamin.

Indikasi media berperan dalam membentuk realitas dapat dilihat dari beberapa hal, seperti pembingkaian peristiwa yang dilaporkannya dan pemberian tanda tertentu pada peristiwa dan siapa tokoh dalam berita (Eriyanto, 2002). Analisis teks melalui framing dapat memberikan hasil yang baik, hal ini melalui cara yang paling transparan, komunikatif dan memberikan gambaran mengenai fakta yang ditampilkan oleh media.. Erving Goffman sejak menggagas framing terus melakukan perkembangan, antara lain dari bidang psikologi, berkembang ke sosiologi dan ditarik menjadi sebuah studi komunikasi. Framing telah digunakan secara aktif dan terbukti penting dalam studi 
komunikasi yang berfokus pada fenomena social seperti krisis, lingkungan, bencana maupun kesehatan (Humphreys \& Thompson, 2014). (Kriyantono, 2020) menjelaskan bahwa pemilihan aspek tertentu dalam suatu fenomena sangat berkaitan dengan pemilihan realitas yang akan mempengaruhi bagaimana aspek tersebut ditulis. Entman merumuskan model framing dengan empat tahapan analisis. Bagaimana masalah tersebut didefinisikan, masalah tersebut berasal dari mana, nilai moral yang ditampilkan dan penyelesaian dari permasalahan tersebut (Kriyantono, 2020).

Pemberitaan yang dilakukan oleh portal berita online dan akun youtube tribunnews.com dilakukan dengan analisis framing melalui empat elemen framing Robert Entman, antara lain identifikasi masalah, masalah disebabkan oleh apa dan penyelesaian masalah. Identifikasi masalah pada tanggal 1-10 Maret 2020 tribunnews lebih menekankan pada pemberitaan mengenai hoax dan pasien positif covid-19. Sedangkan pada tanggal 11-20 pemberitaan mulai berkembang mengenai korban jiwa akibat covid-19. Sedangkan di tanggal 21-31 pemberitaan mengenai penurunan ekonomi di Indonesia, pembatalan perjalanan melalui transportasi pemerintah serta terus bertambahnya korban jiwa.

Diagnose causes atau permasalahan yang terjadi pada tanggal 1-10 Maret 2020 adalah isu covid19 yang merupakan permasalahan baru dan menarik perhatian, membuat para pelaku penyebar hoax tertarik untuk memberitakan informasi yang tidak benar. Pada tanggal 11-20 Maret korban jiwa diakibatkan virus covid-19 yang memiliki penyebaran sangat cepat sehingga potensi tertular sangat tinggi. Sedangkan di tanggal 21-31 Maret 2020 dikarenakan penyebaran yang sangat cepat membuat pemerintah menutup beberapa gerai untuk meminimalisir penurunan kasus, sehingga terjadi penurunan ekonomi. Make moral judgement atau nilai moral dari pemberitaan bulan Maret 2020 adalah pemerintah terus memberikan empati kepada masyarakat, baik yang terdampak ataupun tidak.

Penyelesaian masalah atau treatment recommendation pemberitaan pada tanggal 1-10 Maret 2020 adalah dengan menindak pidana bagi pelaku hoax agar masyarakat dapat lebih tenang dalam menghadapi wabah. Sedangkan pada periode 11-20 Maret pemerintah terus mempersiapkan berbagai rumah sakit untuk mengantisipasi adanya pelonjakan kasus. Yang terakhir tanggal 21-31 adalah pemerintah memberikan ganti rugi terhadap masyarakat yang keberangkatannya dibatalkan akibat pandemi, selain itu pemerintah juga memberikan pelatihan terhadap sektor yang dirugikan akibat pandemi.

Pemberitaan yang disajikan oleh tribunnews berkembang dan dinamis. Penelitian ini berfokus pada analisis teks, namun tidak semua pemberitaan memenuhi keempat unsur framing Robert Entman, portal berita online yang justru berfokus pada teks beberapa pemberitaannya tidak memenuhi empat unsur framing, namun pemberitaan yang disajikan melalui youtube justru memenuhi empat unsur framing tersebut. Konstruksi yang dihasilkan individu dari framing tersebut adalah pada tanggal 1-10 adalah ketenangan dan harapan, sedangkan pada tanggal 11-20 adalah kewaspadaan, dan tanggal 21-31 Maret 2020 adalah kewaspadaan dan ketakutan terhadap pandemi.

Dalam perumusan model framing milik Robert Entman, penulis menemukan bahwasanya tidak semua pemberitaan mengandung empat unsur elemen Framing. Ada satu pemberitaan yang diunggah portal berita tribunnews.com pada tanggal 3 Maret 2020. Pada pemberitaan tersebut tidak ada unsur nilai moral dan penyelesaian dari permasalahan yang diselesaikan. (Eriyanto, 2002) menjelaskan bahwa empat elemen atau empat cara model framing Entman merupakan strategi dari sebuah media, serta membawa sebuah konsekuensi tertentu atas realitas yang terbentuk oleh media. Jika keempat unsur framing tersebut ada yang dihilangkan atau tidak terpenuhi, maka akan mempengaruhi suatu realitas.

Pola yang dihasilkan dari analisis framing bersifat dinamis atau berkembang. Hal ini sesuai dengan sajian data yang peneliti sampaikan melalui tiga periode klasifikasi. Pada periode pertama 
yaitu tanggal 1-10 Maret 2020, pembingkaian yang mendominasi adalah unsur ketenangan. Pada periode kedua 11- 20 Maret 2020, mulai muncul unsur kewaspadaan. Sedangkan pada periode ketiga 21-31 Maret 2020 pola bingkai yang dibentuk adalah ketakutan. Hal ini menggambarkan bagaimana media memberikan informasi yang terus berkembang seiring berjalannya waktu.

Pengelompokan dalam periode sesuai dengan konsep dari (Coombs, 2019) dalam manajemen komunikasi krisis. Pada periode 1 (1-10 Maret 2020) masuk pada tahapan 1 yaitu pra krisis. Tahapan ini menunjukkan bagaimana komunikasi krisis berfokus pada menemukan dan meminimalisir resiko. Pemberitaan yang terjadi kebanyakan menampilkan informasi-informasi mengenai pemerintah yang terus melakukan upaya untuk menanggulangi wabah, antara lain menanggulangi berita-berita hoaks, menyeleksi warga negara asing yang akan mendatangi Indonesia, pemberian informasi untuk penanganan wabah serta himbauan kepada masyarakat untuk tetap tenang. Periode kedua dan ketiga, yaitu pada tanggal 11-31 2020 Maret memasuki tahapan 2, yaitu krisis. Tahap krisis menyatakan bahwa krisis terjadi karena permasalahan sudah menimbulkan dampak yang cukup signifikan. Pada periode ini pemberitaan mayoritas menyajikan kewaspadaan dan ketakutan. Hal ini dikarenakan pemberitaan berisikan informasi mengenai korban jiwa, dampak ekonomi dan kurangnya penanganan masyarakat yang terinfeksi virus.

\section{PENUTUP}

Wabah dan pandemi covid-19 merupakan permasalahan kesehatan yang memicu adanya reportase media. Melalui analisis framing dengan metode framing Robert Entman dengan empat fungsi bingkai yakni bagaima masalah tersebut didefinisikan, darimana asal sumber permasalahan tersebut, nilai moral dalam pemberitaan serta penyelesaian masalah yang ditawarkan oleh media peneliti melihat bingkai 104 pemberitaan yang diunggah pada portal berita online dan akun youtube tribunnews.

Pada periode pertama media membingkai covid-19 sebagai suatu wabah yang bisa diatasi, memberikan informasi-informasi yang menenangkan masyarakat dengan menampilkan peranan pemerintah dalam menghadapi pandemi. Lambat laun pada periode kedua bingkai dirubah menjadi suatu ancaman bagi kesehatan masyarakat dan menjadi suatu resiko yang perlu diwaspadai. Pada periode ketiga framing berisikan kewaspadaan dan ketakutan, covid-19 dinilai sebagai suatu wabah yang menakutkan, menyebar sangat cepat dan menyebabkan kematian, berbagai sektor juga dirugikan seperti penurunan ekonomi dan menyebarnya berita-berita hoaks. Komunikasi kesehatan berguna untuk mempersiapkan publik dalam menghadapi pandemi. Penelitian ini telah menggambarkan bagaimana portal berita online dan youtube dalam membingkai kasus kesehatan dalam konteks informasi yang dinamis atau terus berkembang.

Penelitian ini tentunya beberapa keterbatasan, pertama penelitian ini bertujuan untuk menghasilkan hasil yang terfokus, namun analisis pada satu media yakni tribunnews menunjukkan suatu keterbatasan. Untuk penelitian selanjutnya, bisa dilakukan gambaran yang beragam mengenai bingkai yang dilakukan media-media lain mengenai covid-19 di bulan Maret 2020.

Kedua, penelitian ini hanya terbatas pada bingkai media selama bulan Maret 2020, penelitian di masa depan diharapkan dapat melihat perkembangan wabah dan penanganannya di masa mendatang. Yang terakhir adalah penelitian mendatang bisa melakukan sentimen analisis pada publik untuk mengetahui bagaimana respon atau sikap publik dalam menghadapi suatu pandemi.

\section{Ucapan Terima Kasih}

Penulis mengucapkan terima kasih kepada semua pihak yang terlibat dalam proses penelitian ini. Selain itu, penulis juga mengucapkan terimakasih kepada pengelola, dan reviewer Jurnal Studi 
Komunikasi dan Media yang telah memberikan kesempatan bagi penulis untuk mempublikasikan hasil riset ini.

\section{DAFTAR PUSTAKA}

Assegaf, J. S. (2020). WHO: Pandemi Covid-19 Adalah Krisis Sekali Seabad. https://www.solopos.com/whopandemi-covid-19-adalah-krisis-sekali-seabad-1073664

Berry. (2007). Health communication: Theory and practice. Open University Press.

Briantika. (2020). Telat tangani corona covid-19, pemerintahan Jokowi bisa digugat. https://tirto.id/telattangani-corona-covid-19-pemerintahan-jokowi-bisa-digugat-eG8y

Butsi. (2019). Mengenal Analisis Framing : Tinjauan Sejarah. 1(2).

Chong, D., \& Druckman, J. N. (2016). A Theory of Framing and Opinion Formation in Competitive Elite Environments. Journal of Communication, December 2007. https://doi.org/10.1111/j.14602466.2006.00331.x

Coombs, T. (2019). Ongoing Crisis Communication : Planning, Managing, And Responding. 256.

Eriyanto. (2002). Analisis Framing: Konstruksi, Ideologi, dan Politik Media. PT LKis.

Fahrimal, Y., Husna, A., \& Islami, F. (2020). Media dan Pandemi: Frame Tentang Pandemi Covid-19 dalam Media Online di Indonesia (Studi Pada Portal Berita Kompas.com dan Detik.com). Jurnal Studi Komunikasi Dan MediaStudi Komunikasi Dan Media.

González-padilla, D. A. (2020). Social media influence in the COVID-19 Pandemic Journal of Medical Internet Research, 46(Suppl 1), 120-124. https://doi.org/10.1590/S1677-5538.IBJU.2020.S121

Hinnant, A., Subramanian, R., \& Jenkins, J. (2017). The media logic of health journalism : strategies and limitations in covering social determinants. October 2020, 22-35.

Humphreys, A., \& Thompson, C. J. (2014). Branding Disaster : Reestablishing Trust Systemic Risk Anxieties. 41(December). https://doi.org/10.1086/677905

John, L., \& Foss, K. A. (2011). Teori Komunikasi. Salemba Humanika.

Karman. (2012). Media dan konstruksi realitas. Jurnal Studi Komunikasi Dan Media, 16(1), 27-46.

Karman. (2013). Media Massa dan Konstruksi Realitas (Analisis Framing Terhadap Pemberitaan SKB Menteri Tentang Ahmadiyah di Indonesia pada Suratkabar Harian Suara Pembaruan dan Republika). Jurnal Studi Komunikasi Dan Media, 17(2), 173-186.

Kriyantono, R. (2019a). Apologia Strategies and Ethical Aspects of Government. Jurnal Representamen, $5(02), 32-41$.

Kriyantono, R. (2019b). Disaster Communication In New Media In Government Public Relations Perspectives. https://doi.org/10.4108/eai.7-12-2018.2281803

Kriyantono, R. (2019c). The implementation of the regulation of the Minister of Administrative Reform and Bureaucratic Reform No 29/2011 in crisis management of government public relations. Jurnal Komunikator, 11(2), 93-106.

Kriyantono, R. (2020). Teknik Praktis Riset Komunikasi Kuantitatif dan Kualitatif. Prenada Media Group.

Mulyadi. (2012). Riset Desain Dalam Metodologi Penelitian. Jurnal Studi Komunikasi Dan Media, 16(1), 7180 .

Mutua, S., \& Oloo, D. (2020). Online News Media Framing of COVID-19 Pandemic: Probing the Initial Phases of the Disease Outbreak in International Media Online News Media Framing of COVID-19 Pandemic: Probing the Initial Phases of the Disease Outbreak in International Media. July. https://doi.org/10.30935/ejimed/8402

Negara, S. B., \& Rusadi, U. (2020). Media Siber Pemerintah Menjelang Pemilihan Umum Presiden 2019 The Dynamics Of State Relation And Power in Government Online Media Content Production Towards The 2019 Indonesia Presidental General Election. Jurnal Studi Komunikasi Dan Media, 24(1), 57-72.

Nugroho, A. C. (2016). Informasi kebutuhan dasar dalam liputan media. Jurnal Studi Komunikasi Dan Media, $1986,21-34$.

Ogbodo, J. N., Onwe, E. C., Chukwu, J., Nwasum, C. J., Nwakpu, E. S., Nwankwo, S. U., Nwamini, S., Elem, S., \& Ogbaeja, N. I. (2020). Communicating health crisis: A content analysis of global media framing of COVID-19. Health Promotion Perspectives, 10(3), 257-269. https://doi.org/10.34172/hpp.2020.40

Panuju, R. (2018). Etika Jurnalistik dan Jurnalisme Bencana pada Pemberitaan Gunung Agung di Portal Berita Balipost . com. 219-232.

Putra, M. R. A. (2020). Dampak Broadcast Informasi COVID-19 Melalui WhatsApp Terhadap Kecemasan. https://telisik.id/news/dampak-broadcast-informasi-covid-19-melalui-whatsapp-terhadap-kecemasan--

Quarantelli, E. . (1991). Lessons From Research: Findings On Mass Communication System Behavior In The Pre, Trans, And Postimpact Periods Of Disasters.

Rachmawati, F., Kriyantono, R., \& Toni, A. (2019). Analisis Framing Kegiatan Keislaman Joko Widodo Melalui Portal Berita Setkab.go.id dalam Menjawab Isu Jokowi Antiislam Periode Oktober 2014-Juli 
2018. CHANNEL: Jurnal Komunikasi, 7(1), 19. https://doi.org/10.12928/channel.v7i1.13014

Reese, S. D. (2007). The Framing Project: A Bridging Model for Media Research Revisited. 57, $148-154$. https://doi.org/10.1111/j.1460-2466.2006.00334.x

Rudianto, Komunikasi, I., \& Umsu, F. (2015). Komunikasi dalam Penanggulangan Bencana. 1(April), 51-61.

Sitompul, P. (2014). Konstruksi Realitas Peran KPK Dalam Pemberitaan Online Terkait Kasus Korupsi (Studi Framing Beberapa Pemberitaan Online Terkait Peran KPK pada Kasus Korupsi Mantan Gubernur Banten Ratu Atut Chosiah). Jurnal Studi Komunikasi Dan Media, 28, 169-182.

Sobur, A. (2009). Analisis Teks Media: Suatu Pengantar Untuk Analisis Wacana, Analisis Semiotik, dan Analisis Framing. PT. Remaja Rosdakarya.

Stryker, J. E. (2010). Health communication and journalism (I. W. Donsbach (ed.)). Blackwell Publishing.

Syahri, M. (2009). Analisis Framing Berita Poligami di Media Massa.

Tribunnews. (2020). BNPB Minta Warga Waspadai Berita Hoaks Seputar Virus Corona. https://www.youtube.com/watch?v=6KQ1fhg_qgE\&t=2s

Viswanath. (2010). Health Communication.In W. Donsbach. In The international encyclopedia of communication theories. Blackwell Publishing.

Vos, S. C., \& Buckner, M. M. (2016). Social Media Messages in an Emerging Health Crisis: Tweeting Bird Flu. Journal of Health Communication, 21(3), 301-308. https://doi.org/10.1080/10810730.2015.1064495

Wahyono. (2020). Kapan sebenarnya corona pertama kali masuk ke RI?

Welle, D. (2020). Timeline Penyebaran Virus Corona di Dunia. Detik. https://news.detik.com/dw/d4948386/timeline-penyebaran-virus-corona-di-dunia

Wibhisono, I. G. L. A. K. (2020). Framing Analysis of the Kompas' COVID-19 Coverage: January 2020 Edition. Jurnal ASPIKOM, 5(2), 219. https://doi.org/10.24329/aspikom.v5i2.717

Wutsqa, N. 'Urwatul. (2020). Awas Hoaks Virus Corona, Menkominfo Bakal Proses Hukum Penyebar Hoaks: Indonesia Steril. https://www.tribunnews.com/nasional/2020/03/01/awas-hoaks-virus-coronamenkominfo-bakal-proses-hukum-penyebar-hoaks-indonesia-steril?page=4 
JURNAL STUDI KOMUNIKASI DAN MEDIA

Vol. 25 No. 2 Desember 2021 Hal : 251 - 266 